7. Reprod. Fert. (1971) 27, 427-438

\title{
THE REPRODUCTIVE CYCLE OF THE FEMALE RED DEER, CERVUS ELAPHUS L.
}

\author{
FIONA GUINNESS, G. A. LINCOLN* AND R. V. SHORT \\ Department of Veterinary Clinical Studies, \\ Madingley Road, Cambridge
}

(Received 29th April 1971, revised 18th fune 1971)

Summary. The reproductive physiology and behaviour of red deer hinds on the Isle of Rhum, Scotland, were studied throughout three breeding seasons. The hinds first came into oestrus in the 2nd week of October as yearlings and when 2 and 3 years old. There was no evidence of a silent oestrus with ovulation preceding the first overt oestrus and, in the wild, it seems that most hinds must conceive at the first ovulation of the season. The mean length of the oestrous cycle was $18 \cdot 3 \pm 1 \cdot 7$ days. When animals were not allowed to become pregnant, some continued to come into oestrus until March, showing as many as eight cycles. The mean duration of gestation was $231 \pm 4 \cdot 5$ days $(n=13)$, and one animal gave birth to dizygotic twins of opposite sex. The mean birth weight of calves was $7.5 \pm 1.0 \mathrm{~kg}$. All hinds gained weight during pregnancy, and lost weight during lactation relative to non-pregnant animals.

Most hinds conceived at the first oestrus in which they were mated, even if this was late in the season. There was a high incidence of maternal agalactia in hinds that calved late, which would normally have resulted in the death of the calf. Most hinds had an accessory ovulation early in pregnancy, which was not associated with oestrous behaviour.

Oestrous behaviour was recorded on more than 120 occasions and was least pronounced at the beginning and end of the mating season. Oestrus seldom lasted more than $24 \mathrm{hr}$. Matings were equally frequent by day or night; a stag might mount a hind many times before ejaculating, or succeed at the first attempt. Hinds were sometimes served more than once at a given oestrus, and by more than one stag.

The vaginal mucus at oestrus had a strong, penetrating smell and throughout the mating season there was a second odour which was sweet and musty. If a hind had been served by a stag, it was possible to smell his rutting odour on her rump. A hind's position in the social hierarchy did not change at oestrus, but some became much more aggressive towards subordinates and demonstrative towards humans. Homosexual behaviour was sometimes seen if two hinds were in oestrus simultaneously.

* Unit of Reproductive Biology, Life Sciences Building, Crown Street, P.O. Box 147, Liverpool L69 3BX. 


\section{INTRODUCTION}

Red deer hinds in Britain calve principally in late May and early June, after a short rutting season in the previous September and October (Fraser Darling, 1937; Whitehead, 1950; Zuckerman, 1952). Both the stag and the hind are fertile for several months after the end of the normal rut, and a few calves are born as late as October or November. Spermatogenesis in the stag continues throughout the period when the antlers are in 'hard horn', from August until the following March (Lincoln, 1971), whilst hinds first come into oestrus in October. If they do not become pregnant, they can continue to have regular oestrous cycles until the following March (Lincoln, Youngson \& Short, 1970).

This communication describes the breeding season of red deer hinds in detail, with particular reference to the oestrous cycle and the behavioural signs of oestrus.

\section{MATERIALS AND METHODS}

Eleven newborn hind calves were caught on the Isle of Rhum $\left(57^{\circ} 0^{\prime} \mathrm{N}, 6^{\circ}\right.$ $20^{\prime} \mathrm{W}$ ), Scotland, during June 1967 and hand-reared (Youngson, 1970). They were subsequently released into a 35-acre fenced enclosure on the island, consisting of mixed deciduous and coniferous woodland and poor heather and Molinia hill grazing. Throughout the winter months, they were given supplementary feed.

At the beginning of September 1968, a raddled, vasectomized stag was introduced into the enclosure, and the raddle harness (Sire-Sine) and crayon were replaced from time to time. During the 1968 mating season, some hinds were turned out of the enclosure on the day of oestrus, and two became pregnant to wild stags.

In June 1969, a second stag, a hummel with a congenital absence of antlers (Lincoln \& Short, 1969), was introduced into the enclosure. This stag was also fitted with a raddle harness and, since he was always subordinate to the vasectomized stag, it was possible to arrange a fertile mating when desired by removing the vasectomized animal. The hinds were so tame that they could normally be handled with ease, but the stags had to be immobilized with Etorphine when restraint was required (Lincoln et al., 1970).

An additional wild hind was introduced into the enclosure in 1970, and daily observations were maintained on all the hinds from September until March in 1968-69, 1969-70 and 1970-71. Each animal was inspected for signs of mating in the morning and again in the afternoon, and the social hierarchy was determined by recording the behaviour of the hinds around the feeding troughs.

Blood samples were collected from a number of the hinds in the 1970-71 mating season for progesterone determinations. The animals were restrained with the aid of Rompun (Bayer), given intramuscularly at a dosage of 0.1 $\mathrm{mg} / \mathrm{kg}$, using a $10 \%$ solution of the drug. At this dosage, the animals could barely stand and it was a simple matter to collect blood from the jugular vein. The blood was heparinized, centrifuged and the plasma stored in a deep-freeze until required for assay. Progesterone was measured by the competitive protein binding procedure of Thorburn, Bassett \& Smith (1969). 
The body weights of the hinds were measured from time to time by encouraging them into a crate which was suspended from a spring balance.

\section{RESULTS}

Time of onset of oestrus

The raddled, vasectomized stag served the first hind during the 2nd week of October in each of the 3 years of this study (see Table 1). There was no significant difference in the mean date of onset of oestrus for the group between years, suggesting that, contrary to popular belief, the time of onset of oestrus is not influenced by the hind's age. The order in which the animals came into oestrus varied between years, and was not apparently correlated either with body weight or social rank. Two lactating hinds (Nos. 7 and 10; see Table 1)

TABLE 1

BODY WEIGHT, DATE OF ONSET OF OESTRUS, AND LENGTH OF MATING SEASON IN RED DEER HINDS

\begin{tabular}{|c|c|c|c|c|c|c|c|c|c|}
\hline \multirow[b]{2}{*}{$\begin{array}{l}\text { Hind } \\
\text { no. }\end{array}$} & \multicolumn{3}{|c|}{$1968-69$} & \multicolumn{3}{|c|}{$1969-70$} & \multicolumn{3}{|c|}{$1970-71$} \\
\hline & $\begin{array}{c}\text { Body } \\
w t \\
\langle k g)\end{array}$ & $\begin{array}{c}\text { First } \\
\text { oestrus }\end{array}$ & $\begin{array}{c}\text { Last } \\
\text { oestrus }\end{array}$ & $\begin{array}{c}\text { Body } \\
w t \\
(k g)\end{array}$ & $\begin{array}{c}\text { First } \\
\text { oestrus }\end{array}$ & $\begin{array}{c}\text { Last } \\
\text { oestrus }\end{array}$ & $\begin{array}{c}\text { Body } \\
w t \\
(\mathrm{~kg})\end{array}$ & $\begin{array}{c}\text { First } \\
\text { oestrus }\end{array}$ & $\begin{array}{c}\text { Last } \\
\text { oestrus }\end{array}$ \\
\hline $\begin{array}{r}1 \\
2 \\
3 \\
4 \\
5 \\
6 \\
7 \\
8 \\
9 \\
10 \\
11 \\
12 \\
\text { (wild } \\
\text { hind) }\end{array}$ & $\begin{array}{l}72 \cdot 7 \\
78.2 \\
75 \cdot 0 \\
70 \cdot 5 \\
75.5 \\
77 \cdot 3 \\
75.9 \\
75.9 \\
78.2 \\
80.0 \\
68 \cdot 2 \\
-\end{array}$ & $\begin{array}{r}19 \text { Oct. } \\
29 \text { Oct. } \\
25 \text { Oct. } \\
30 \text { Oct. } \\
18 \text { Oct. } \\
18 \text { Oct. } \\
2 \text { Nov. } \\
13 \text { Oct. } \\
23 \text { Oct. } \\
31 \text { Oct. } \\
26 \text { Oct. } \\
\text { - }\end{array}$ & $\begin{array}{c}10 \text { March } \\
26 \text { Feb. } \\
12 \text { Jan. } \\
17 \text { Nov. } \\
5 \text { Nov.* } \\
21 \text { March } \\
18 \text { Nov.* } \\
21 \text { March } \\
29 \text { Dec. } \\
8 \text { Dec. } \\
10 \text { Feb. } \\
-\end{array}$ & $\begin{array}{l}84.5 \\
90 \cdot 0 \\
84.5 \\
83.6 \\
84.5 \\
95.5 \\
85.9 \\
91.4 \\
93.6 \\
94.5 \\
79.1 \\
-\end{array}$ & $\begin{array}{c}13 \text { Oct. } \\
22 \text { Oct. } \\
16 \text { Oct. } \\
19 \text { Oct. } \\
21 \text { Oct. } \dagger \\
25 \text { Oct. } \\
19 \text { Dec. } \dagger \\
24 \text { Oct. } \\
18 \text { Oct. } \\
12 \text { Nov. } \\
2 \text { Nov. } \\
-\end{array}$ & $\begin{array}{r}4 \text { Dec.* } \\
9 \text { Dec.* } \\
24 \text { Nov.* } \\
19 \text { Jan.** } \\
25 \text { Nov.* } \\
15 \text { Dec.* } \\
15 \text { Feb.* } \\
12 \text { Jan.* } \\
22 \text { Jan.* } \\
25 \text { Jan.* } \\
16 \text { Feb.* } \\
\text { - }\end{array}$ & $\begin{array}{l}84 \cdot 5 \\
89 \cdot 5 \\
87 \cdot 3 \\
\\
94 \cdot 1 \\
97 \cdot 7 \\
96 \cdot 8 \\
84 \cdot 5 \\
-\end{array}$ & $\begin{array}{l}13 \text { Oct. } \dagger \\
13 \text { Oct. } \ddagger \\
11 \text { Oct. } \dagger \\
29 \text { Oct. } \ddagger \\
17 \text { Nov. } \ddagger \\
16 \text { Oct. } \ddagger \\
20 \text { Dec. } \dagger \\
10 \text { Nov. } \ddagger \\
13 \text { Oct. } \dagger\end{array}$ & $\begin{array}{r}1 \text { Feb. } \\
6 \text { Dec.* } \\
11 \text { Oct.* } \\
13 \text { Nov.** } \\
7 \text { Dec.* } \\
24 \text { Oct.* } \\
27 \text { Jan.* } \\
26 \text { Nov.* } \\
5 \text { Nov.* }\end{array}$ \\
\hline
\end{tabular}

* Animal served at this oestrus and conceived.

$\dagger$ Animal lactating and with calf at foot.

$\ddagger$ Animal failed to lactate and so calf died.

were unusually late in coming into oestrus. However, four other hinds with calves at foot at the beginning of the mating season came into oestrus at the normal time. The wild hind introduced into the enclosure early in 1970 came into oestrus for the first time on 13th October that year, and so behaved in the same way as the hand-reared animals. All the hinds in the enclosure came into oestrus at some time in each of the three seasons.

\section{'Silent' oestrus}

In order to establish whether the hinds in the enclosure could have ovulated before the first overt oestrus in October, blood samples were collected on a number of occasions before the first oestrus and assayed for progesterone. The 
results are shown in Table 2. In all of the fourteen samples collected from seven different hinds before the first oestrus, progesterone was only present in insignificant amounts $(0.4 \mathrm{ng} / \mathrm{ml}$ plasma or less), whilst two samples taken after the first oestrus both contained a significant amount of the hormone ( 3 to 4 $\mathrm{ng} / \mathrm{ml}$ plasma). These results indicate that the majority of animals in the group did not have an active corpus luteum before the onset of the first behavioural oestrus.

TABLE 2

CONCENTRATION OF PROGESTERONE IN THE PLASMA OF RED DEER HINDS BEFORE AND AFTER THE FIRST OVERT OESTRUS OF THE MATING SEASON

\begin{tabular}{c|c|cccc}
\hline & $\begin{array}{c}\text { Date } \\
\text { Hind } \\
\text { no. first } \\
\text { oestrus }\end{array}$ & \multicolumn{5}{|c}{ Progesterone concentration } \\
\hline 3 & 13 Oct. & 26 Sept. & 7 Oct. & 12 Oct. & 24 Oct. \\
\hline 4 & 13 Oct. & - & $0 \cdot 2$ & $0 \cdot 2$ & $3 \cdot 3$ \\
5 & 11 Oct. & $0 \cdot 2$ & -2 & 0 & $4 \cdot 0$ \\
8 & 17 Nov. & - & 0 & 0 & $0 \cdot 3$ \\
9 & 16 Oct. & - & 0 & $0 \cdot 4$ & 0 \\
10 & 20 Dec. & 0 & - & - & $0 \cdot 1$ \\
11 & 10 Nov. & - & - & 0 & $0 \cdot 2$ \\
\hline
\end{tabular}

Results expressed as ng progesterone/ml plasma.

Length of the oestrous cycle

The mean length of the oestrous cycle, based on seventy-eight cycles, of all the hinds in the enclosure over the 3 years was 18.3 days \pm S.D. $1 \cdot 7$ (see Table 3 ). There was no significant difference between yearly means, although there was a tendency for cycle length to decrease with increasing age. In addition, cycle lengths within a single mating season tended to increase as the season progressed (see Table 4). Five short cycles of 7 to 9 days and nine long cycles of 34 to 59 days (see Text-fig. 1) have been excluded from these calculations.

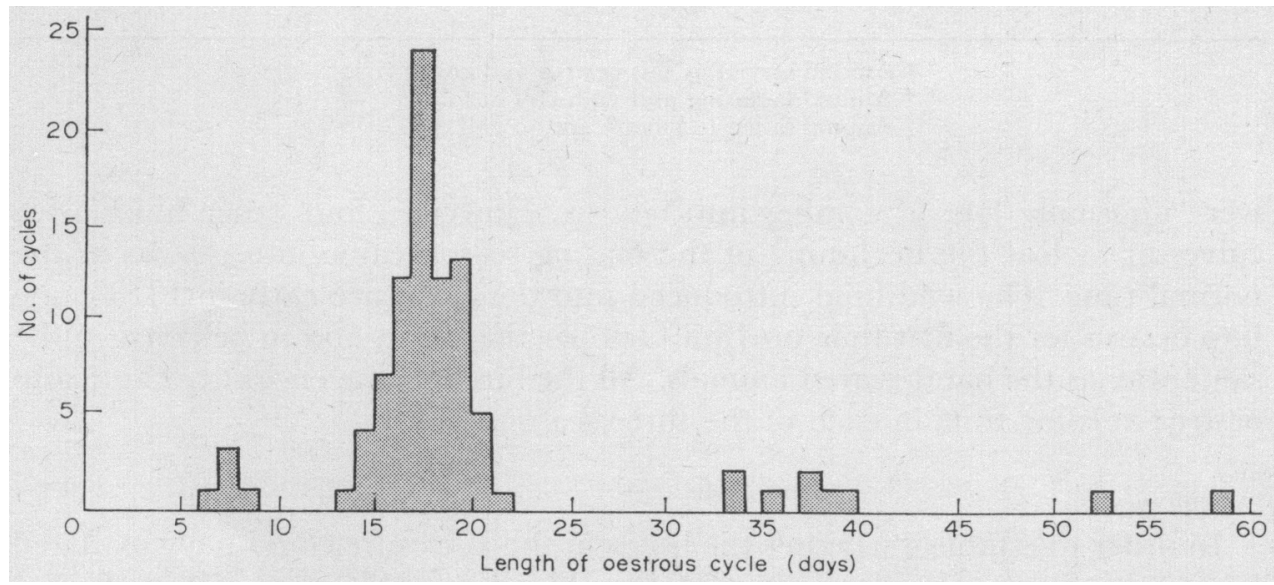

TEXT-FIG. I. The incidence of short, normal and long oestrous cycles shown by the hinds between 1968 and 1970 . 
TABle 3

LENGTH OF THE OESTROUS GYCLES OF RED DEER HINDS IN 1968, 1969 AND 1970

\begin{tabular}{|c|c|c|c|}
\hline \multirow[b]{2}{*}{ Hind no. } & \multicolumn{3}{|c|}{$\begin{array}{c}\text { Mean length of oestrous cycle (days) } \\
\text { (No. of cycles in parentheses) }\end{array}$} \\
\hline & $1968-69$ & $1969-70$ & $1970-71$ \\
\hline \multirow{13}{*}{$\begin{array}{l}1 \\
2 \\
3 \\
4 \\
5 \\
6 \\
7 \\
8 \\
9 \\
10 \\
11 \\
12 \text { (wild hind) }\end{array}$} & $19 \cdot 3(4)$ & $17 \cdot 3(3)$ & - \\
\hline & $16.7(3)$ & $16.0(3)$ & 二 \\
\hline & $19 \cdot 5(2)$ & $19.5(2)$ & $18 \cdot 3(6)$ \\
\hline & 18.0 (1) & $16.5(2)$ & $17 \cdot 7(3)$ \\
\hline & $18 \cdot 0(1)$ & $17 \cdot 5(2)$ & - \\
\hline & $18.6(5)$ & $17.0(3)$ & - \\
\hline & $16 \cdot 0(1)$ & $19 \cdot 3(3)$ & $14 \cdot 0(1)$ \\
\hline & $20.5(4)$ & $20.0(4)$ & $20.0(1)$ \\
\hline & $20 \cdot 0(2)$ & $19 \cdot 2(5)$ & \\
\hline & $19.0(2)$ & $18 \cdot 5(4)$ & $17 \cdot 0(2)$ \\
\hline & $20 \cdot 0$ (1) & $17 \cdot 7(6)$ & $16.0(1)$ \\
\hline & - & - & $15 \cdot 0(1)$ \\
\hline & $18 \cdot 9 \pm$ S.D. $1 \cdot 6$ & $18 \cdot 2 \pm$ S.D. $1 \cdot 5$ & $17 \cdot 5 \pm$ S.D. $1 \cdot 7$ \\
\hline
\end{tabular}

Day of onset of oestrus = Day 0 of cycle.

The short cycles occurred at the beginning of the mating season in one animal in 1968 and in two animals in 1970, and were about half the normal cycle length. The long cycles occurred mainly in the first season when the hinds were yearlings. Since they appeared to be multiples of the normal cycle length, it is possible that the stag failed to detect oestrus or the crayon failed to mark the hind. However, we are certain that some of these animals failed to show any signs of oestrus at the expected time.

TABLE 4

LENGTH OF OESTROUS CYGLES OF RED DEER HINDS IN RELATION TO STAGE OF THE MATING SEASON

\begin{tabular}{l|cccccc}
\hline & \multicolumn{7}{|c}{ Stage of breeding season } \\
& First & Second & Third & Fourth & Fifth & Sixth \\
& cycle & cycle & cycle & cycle & cycle & cycle \\
\hline $\begin{array}{l}\text { Mean cycle length } \\
\text { No. of cycles }\end{array}$ & $17 \cdot 8 \pm 1 \cdot 7$ & $18 \cdot 2 \pm 1 \cdot 7$ & $18 \cdot 8 \pm 1 \cdot 7$ & $19 \cdot 1 \pm 1 \cdot 1$ & $18 \cdot 3$ & $19 \cdot 0$ \\
& 29 & 21 & 14 & 7 & 4 & 2 \\
\hline
\end{tabular}

\section{Length of the mating season}

We were only able to determine the maximum possible length of the mating season for nine animals in 1968-69, and one animal in 1970-71; on other occasions, the animals were allowed to become pregnant (see Table 1). But in 1968-69 and 1969-70, all the hinds came into oestrus at least twice and most continued to cycle until January. In 1968-69, three hinds had their last oestrus in March, having had as many as eight cycles during the course of the mating season. 
TABLE 5

GESTATION LENGTH OF HINDS AND WEIGHTS OF NEWBORN GALVES

\begin{tabular}{|c|c|c|c|}
\hline $\begin{array}{l}\text { Hind } \\
\text { no. }\end{array}$ & $\begin{array}{c}\text { Gestation length } \\
\quad \text { (days) }\end{array}$ & $\begin{array}{l}\text { Wt of } \\
\text { calf } \\
(k g)\end{array}$ & $\begin{array}{c}\text { Sex } \\
\text { of } \\
\text { calf }\end{array}$ \\
\hline $\begin{array}{r}1 \\
2 \\
3 \\
4 \\
5 \\
5 \\
6 \\
7 \\
7 \\
8 \\
9 \\
10 \\
11\end{array}$ & $\begin{array}{l}238 \\
223 \\
226 \\
226 \\
227 \\
235 \\
233 \\
229 \\
236 \\
231 \\
236 \\
229 \\
234\end{array}$ & $\begin{array}{c}8 \cdot 0 \\
8 \cdot 0 \\
8 \cdot 0 \\
5 \cdot 5 \\
9 \cdot 1 \\
8 \cdot 2 \\
7 \cdot 0 \\
7 \cdot 5 \\
6 \cdot 1,6 \cdot 1 \\
\overline{8 \cdot 0} \\
7 \cdot 7 \\
8 \cdot 0\end{array}$ & $\begin{array}{c}0 \\
0 \\
0 \\
0 \\
0 \\
0 \\
0 \\
0 \\
0 \\
0 \\
0 \\
0 \\
0 \\
0 \\
0 \\
0 \\
0 \\
0 \\
0 \\
0\end{array}$ \\
\hline Mean \pm S.D. & $231 \cdot 0 \pm 4 \cdot 5$ & $7 \cdot 5 \pm 1 \cdot 0$ & \\
\hline
\end{tabular}

Day of mating = Day 0 of pregnancy.

Duration of gestation and birth weight of calves

The mean duration of gestation of the hinds in the enclosure, based on thirteen observations, was 231 days \pm 4.5 S.D. (see Table 5). In both cases where a hind became pregnant in 2 successive years, the second pregnancy was about 7 days longer than the first. One animal that gave birth to twins had a

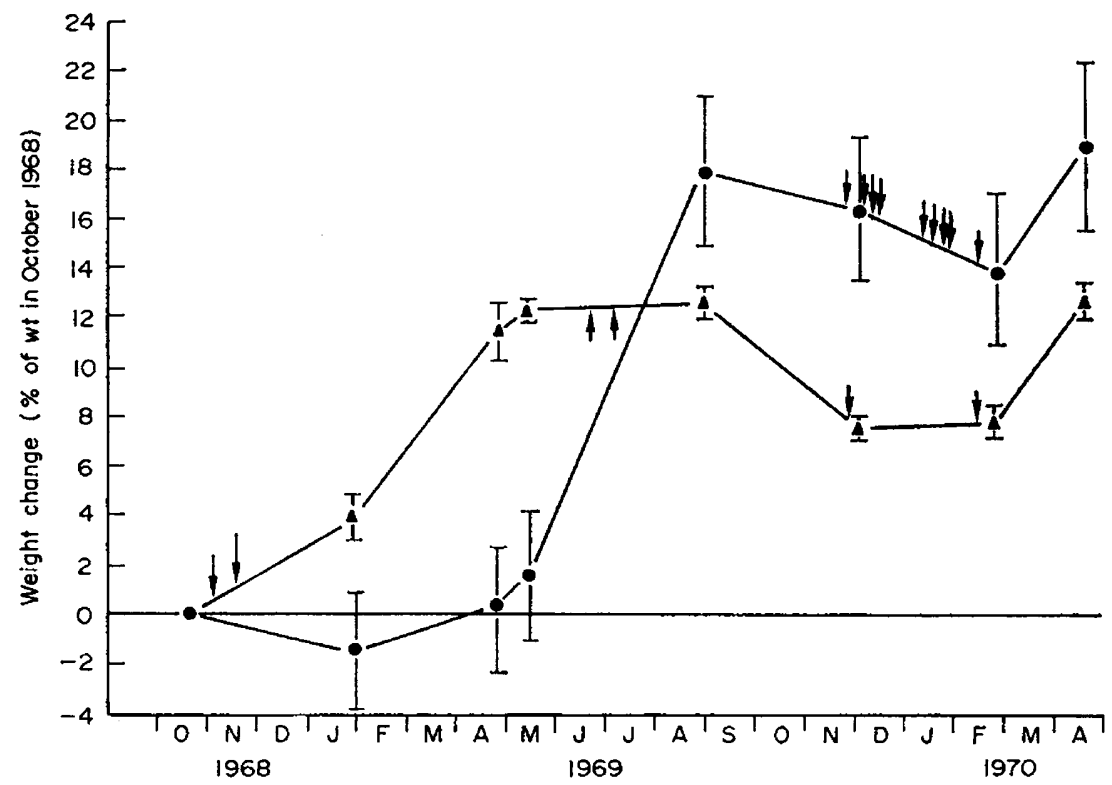

TExT-FIG. 2. Changes in body weight shown by two pregnant (mean and range) and nine non-pregnant (mean and S.D.) yearling hinds between October 1968 and April 1970. Results are expressed as \% of body weight in October 1968. $\Delta$, Pregnant animals; , non-pregnant animals; $\downarrow$, conception; $\uparrow$, calving. 
normal gestation length (236 days). The mean birth weight of the calves was $7.5 \mathrm{~kg} \pm 1 \cdot 0$ S.D.

\section{Change in body weight of hinds during pregnancy and lactation}

The two hinds that became pregnant as yearlings increased in weight more than the nine non-pregnant ones (see Text-fig. 2). After they had calved the following summer, the situation was reversed. It was now the non-pregnant animals that put on weight, so that by the autumn they were about $6 \%$ heavier and in better bodily condition than the two lactating animals. The increased weight of the hinds during pregnancy could be almost completely accounted for by the known weights of the developing conceptuses (Mitchell, personal communication).

\section{Oestrous behaviour}

The oestrous behaviour of hinds was observed on more than 120 occasions during the 3 years of this study, and whilst there was great individual variation, it is possible to describe the main behavioural characteristics.

(a) Relations between the oestrous hind and the stag. Usually, the first indication that a hind was coming into oestrus was when the stag showed a tendency to keep within 10 to $15 \mathrm{~m}$ of her, and the two animals could often be found resting close to one another. The stag usually appeared to guard the hind, standing between her and other animals or the observer and making threatening gestures, such as grinding his teeth or presenting his antlers. This type of behaviour could occur up to $12 \mathrm{hr}$ before the hind was in full oestrus and would accept mating.

As oestrus advanced, the stag would begin to take a more active interest in the hind, and when she came close to him he might make a sudden dash towards her, flicking out his tongue with head stretched forward and nose directed towards her tail. The hind invariably retreated quickly from these advances with her tail sometimes raised in the air and the stag would pursue her for 10 to $15 \mathrm{~m}$; the chase would often end in the stag giving a series of loud roars.

If the oestrous hind was lying down, the stag would make her stand by placing his chin on her back or rump, and as she got up and moved away, he might pursue her, or merely stand and smell the area where she had been lying. The movements of the hind were watched and if she urinated, the stag would dash up, sniff out the exact spot, and then show flehmen.

When this type of courtship behaviour had gone on for some time, the hind gradually became more and more reluctant to run away, and would allow the stag to place his chin on her rump during the chase or lick her vulva. Occasionally, the hind would solicit the stag, trotting past him with her head held low and neck extended whilst making a characteristic chewing action with her mouth open.

Ultimately, during one of the chases, the hind would come to a sudden halt and stand with her back slightly arched, ears back, and tail raised. Mating would then follow immediately (see Pl. 1, Fig. 1). After mounting, the stag would pause momentarily to achieve intromission. Then, after a few mild 
pelvic thrusts, he would lunge violently upwards from his hind quarters so that his legs left the ground and his body assumed an almost vertical position. The force of this ejaculatory thrust usually pushed the hind forwards a few paces, and the stag dismounted in the process.

After such a mating, the hind might commence grazing; more commonly, she would stand for a minute or two with her back arched, ears laid back and hind legs slightly splayed. She would strain the abdominal muscles, urinate, defaecate, and might pass clear mucus from the vulva. Sometimes she would flare her rump patch. The stag usually roared repeatly after mating, and would often urinate. He would stand still for periods of several minutes with his head held low, staring in front of him. He would eventually revert to guarding the hind again.

A stag would sometimes make several mounting attempts before giving the ejaculatory thrust. On one exceptional occasion, the hummel was seen to mount a hind thirty-four times within a space of $2 \mathrm{hr}$ without apparently ejaculating. But, in general, it was rare for a stag to fail to show a complete mating sequence culminating in ejaculation, and most hinds conceived at the first oestrus on which they were allowed to be mated by the hummel. After ejaculation, the stag would not attempt to mate again for 20 to $30 \mathrm{~min}$, although the stag and hind often remained together. The hind would occasionally rub her head and body against the stag, or sniff at his tail, whilst he would lick her vulva or udder (Pl. 1, Fig. 2). Frequently, the stag would prod the oestrous hind in the flank or ribs with his antlers or forehead just before mating (Pl. 2, Fig. 3). The oestrous hind would twist her head and yawn more frequently than usual, rub her head and neck against branches or posts, and stand bobbing her head up and down.

There were marked differences between individual hinds in the type and intensity of their oestrous behaviour. Some animals were apparently served only once at a given oestrus and showed only the most subtle signs that they were in heat. Other animals showed conspicuous oestrous behaviour and were served four or five times. Similarly, the duration of oestrus was variable, but only in three cases were hinds served over a period of more than $24 \mathrm{hr}$. Frequently, components of oestrous behaviour were shown for more than $24 \mathrm{hr}$, and up to 4 days in extreme cases; oestrus appeared to be extended if the hind was not allowed to be served by a stag. On a number of occasions, a hind was served by two different stags at one oestrus. The oestrous behaviour was least pronounced at the beginning and end of the mating season, and more conspicuous in November to January.

Matings took place both during the day and night. In 1968-69, hinds were first marked by the stag during the daytime on fourteen occasions, and during the night or early morning on eighteen occasions. In 1969-70, hinds were observed in oestrus on thirty-nine occasions, and mating occurred during the day in twenty of them.

(b) Relations between the oestrous hind and other hinds. There was a well-developed and relatively stable social hierarchy within the hind group, with a number of triangular relationships. This hierarchy was not apparent when the animals were under a year old, and appeared to develop a few months before they first 
PISTE!
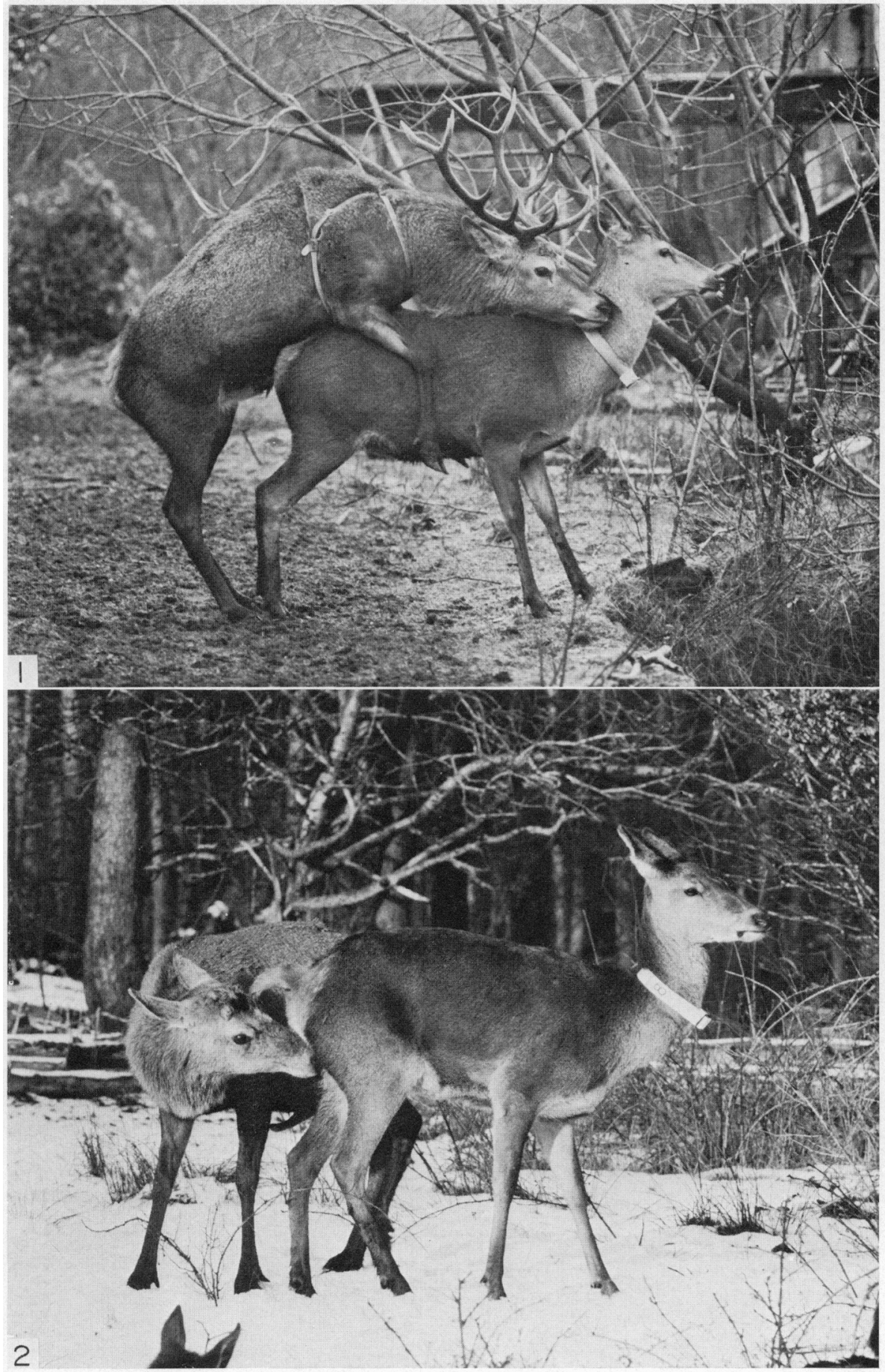

Fir. l. Vasectomized stag wearing a made harness serving Hind No. 9 at her fifth ocstrus of the season on Jish December 1969.

life. 2. Hummel stag nosing the perineal region of a hind between mating attempts. Vute the arched back. raised tail and cars kad back. all trpical features of the more cxaggetated signs of ocstrus seen at this time of the year fiste Februaty 1970). The hind concerised twins at this oestrus. 

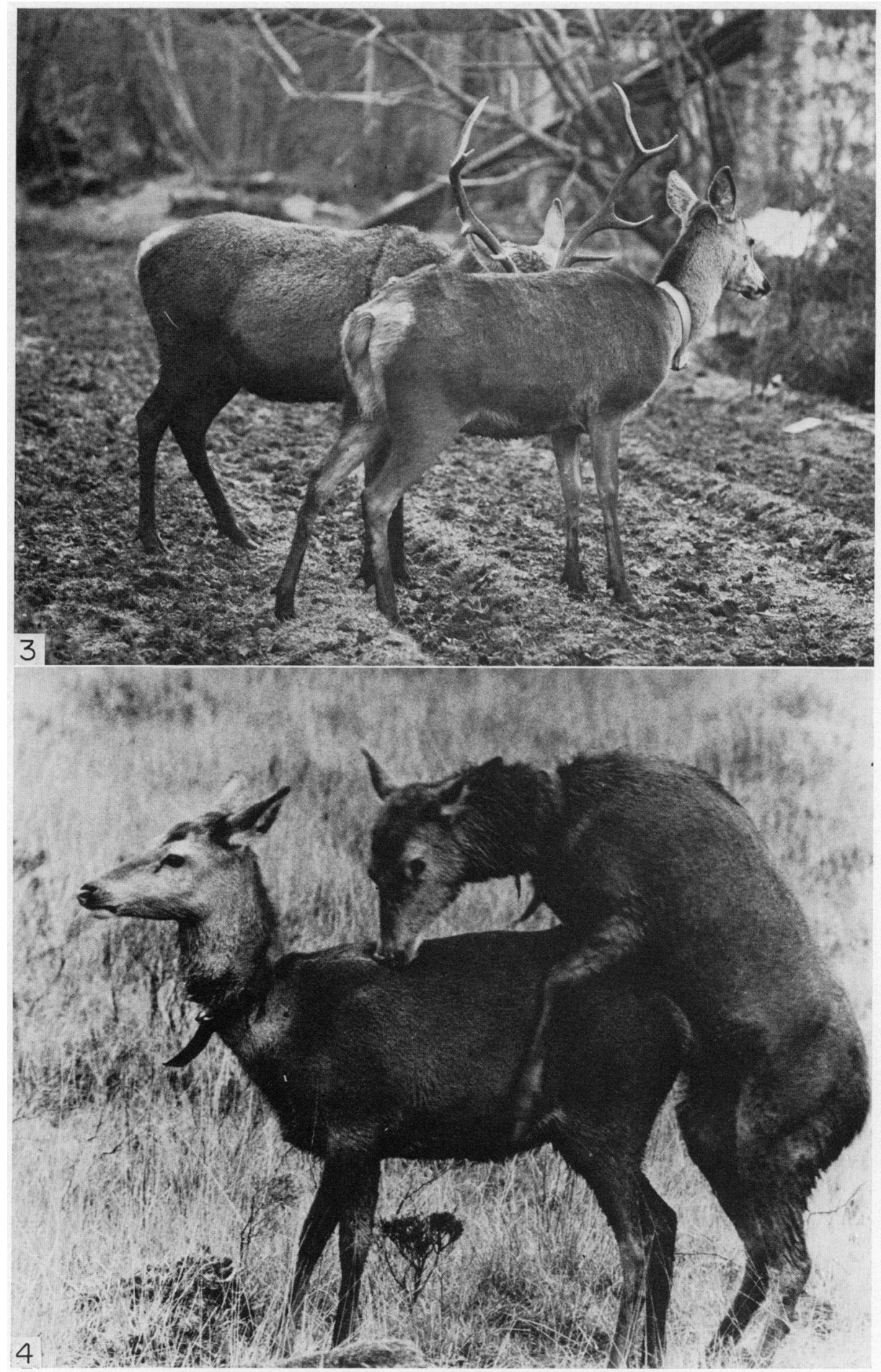

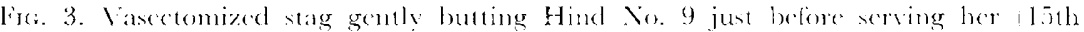
1) cember 1969

I. If. 4. Two hinds in antus showing homesexual behavioun. 
came into oestrus. Once the social rank was established, it did not change when a hind came into oestrus. However, some oestrous animals would go out of their way to chase and bite subordinate individuals. A hind in oestrus often placed her chin on the back or rump of other animals and, when two hinds were in oestrus at the same time, they would sometimes mount one another (PI. 2, Fig. 4). It may be significant that, although the hand-reared hinds failed to develop a social hierarchy as calves, their offspring showed dominance behaviour within a few weeks of birth.

(c) Relations between the oestrous hind and the observer. When a hind was in oestrus, she usually allowed pressure to be applied to her rump without ducking away. If a hand was placed on her back when she was walking, she would often stop, arch her back slightly and wag her tail. When in oestrus, the hind usually allowed one to handle her a great deal more, permitting one to stroke the belly and udder. When the perineal region was touched, she would often raise her tail and discharge mucus from the vulva. Some animals even allowed one to collect vaginal smears, although they would not do so at any other stage of the cycle. The oestrous hind would often rub against the observer with the tail raised and wagging, and she would even attempt to mount by rearing up on her hind legs and placing her forefeet on one's head or shoulders.

(d) Other signs of oestrus. Hinds developed a sweet, musty smell around the tail each year before first coming into oestrus. This smell faded away by the end of the mating season in March. It was even present in one of the hind calves that was tame enough to be examined, but in this case it only persisted for 1 or 2 months. The smell was sometimes more noticeable at oestrus, when there was invariably a second strong, penetrating odour coming from the vaginal mucus. In the early stages of oestrus, clear fluid mucus dripped from the vagina and from the end of the tail; later on, it became more viscous and cloudy. Histological examination of vaginal smears taken from three oestrous animals revealed weak 'ferning' in only one case.

Any animal that had been mounted by the stag smelt strongly of his rutting odour, and this sometimes persisted for over 2 weeks. The presence of roughened hair on the middle of the back is a useful field guide for detecting a hind that has recently been served by a stag; the stag's fore feet may also leave muddy marks on the hind's flanks.

\section{DISCUSSION}

The sexual behaviour of red deer has been a subject of considerable historical as well as scientific interest. Turbervile (1576), in a translation of Jacques du Fouilloux's La venerie et l'adolescence (1561), graphically describes how during the rut the stag 'will begin to vault, and to bellow, casting him selfe with a full leape upon the Hynde to cover hir, and that quickly'. He also gives what must be one of the first descriptions of flehmen: 'For when they smell the Hynde, they rayse their nose up into the ayre, and looke aloft, as though they gave thankes to nature which gave them so great delight.' Almost a century later, William Harvey (1651) was led sadly astray by his failure to find the products of conception in the uterus at the time of the rut. Walter Heape (1901) noted 
that hinds are seasonally polyoestrous, and Fraser Darling (1937) observed copulation in the middle of October. MacNally (1968) noted that a tame hind came into oestrus for about $24 \mathrm{hr}$ approximately every 21 days during the autumn and winter.

Our results with a vasectomized stag clearly show that red deer hinds are seasonally polyoestrous, with cycles of about 18 days in length from October to March in some animals. The captive hinds came into oestrus first as yearlings, though few wild hinds on Rhum conceive before they are 2 years old (Lowe, 1969). This difference is almost certainly due to the improved plane of nutrition of the captive animals, which were considerably heavier than wild animals of the same age.

No captive hind came into oestrus before mid-October, and the absence of progesterone before the first overt oestrus indicated that there had been no silent oestrus with ovulation earlier. None of nineteen hinds shot near the beginning of the rut, from 5th to 25th September, had ovulated, although all had large follicles in the ovaries. A wild hind that died suddenly in the enclosure on 9th October had not ovulated. Lincoln et al. (1970) found the first evidence of ovulation in a hind shot on 2nd October.

'Silent heats' are common in domestic sheep, particularly at the beginning of the breeding season (Grant, 1934; Robinson, 1959), and they probably occur in wild ungulates like the elk, Cervus canadensis (Morrison, 1960), moose, Alces alces (Simkin, 1965) and Uganda kob, Adenota kob thomasi (Buechner, Morrison \& Leuthold, 1966). A few of our hinds showed unusually short oestrous cycles at the beginning of the mating season, as in sheep (Land, 1971); Thomas (1970) found that, in black-tailed deer, Odocoileus hemionus columbianus, such short cycles are associated with small, short-lived corpora lutea. The long cycles that we found appeared to be multiples of the normal cycle length, and some could have resulted from our inability to detect oestrus.

Ovulation during pregnancy is a common event in red deer (Douglas, 1966); the ovaries of fifty-two pregnant hinds shot on Rhum between October and January were examined, and twenty-seven of them had a small accessory corpus luteum (average diameter, $4.7 \mathrm{~mm}$ ) in addition to the large $(9.3 \mathrm{~mm}$ ) primary corpus luteum of pregnancy. The accessory corpus luteum seemed to be formed in November or December following an actual ovulation. Presumably some of our tame hinds would also have formed accessory corpora lutea, but it was interesting that none of them ever showed any signs of oestrus during pregnancy.

Prell (1938) recorded the gestation length of nine red deer from Germany as $233.7 \pm 3.5$ days; this is similar to our figure of $231.0 \pm 4.5$ days, based on thirteen observations. Using this information and the fact that, on Rhum, the highest incidence of calvings occurs in the first week of June, it is possible to calculate that the peak incidence of conceptions must occur in the middle of October. Although this is in complete agreement with the time at which we first observed oestrus in the tame hinds, stags on Rhum start showing rutting behaviour and herding hinds about a month before this (Lincoln et al., 1970).

Twin pregnancies are extremely rare in red deer and, on Rhum, only one previous case has been recorded in 10 years, although over 1000 reproductive 
tracts have been examined (Mitchell, personal communication). One of the tame hinds in this study produced male and female twins. The hind had one calf the previous year, and appeared to be in relatively poor condition when mated in February.

In the 2nd year of the project, matings were spaced out from October to February in order to study the duration of lactational anoestrus and the survival of late calves. The shortest interval between calving and oestrus in a lactating hind was 10 weeks, but if the calf was lost at birth so that the hind stopped lactating, this interval was as short as 20 days. This difference may be an effect of lactation itself, or a more general effect of bodily condition. Most of the lactating hinds were in relatively poor condition, and two of them which were late in showing oestrus came into heat soon after receiving supplementary feed. On Rhum, about $85 \%$ of mature hinds that are not lactating become pregnant, as compared to only $50 \%$ of lactating animals (Mitchell, personal communication).

Of the six hinds that calved unusually late in the season (August to October), only one lactated normally and was able to rear its offspring. In all the other cases, the udder was poorly developed at parturition and little milk could be expressed from the teats even though the animals were in good bodily condition. This lactational failure would certainly lead to the death of most late calves in the wild, but might have a hidden advantage since it would allow the hind to regain condition and come into oestrus at the normal time the following year.

\section{ACKNOWLEDGMENTS}

We would like to express our particular thanks to Mr R. W. Youngson for handrearing the hinds used in this study, and for carrying out a number of the initial observations on them. We are also most grateful to the Nature Conservancy and their staff on Rhum for giving us every assistance, and to Dr Brian Mitchell for access to unpublished information. We are indebted to Dr David Jenkins for his advice and encouragement throughout the course of this work, which was made possible by generous grants from the Natural Environment Research Council.

\section{REFERENGES}

Buechner, H. K., Morrison, J. A. \& Leuthold, W. (1966) Reproduction in Uganda kob with special reference to behaviour. Symp. zool. Soc. Lond. 15, 69.

Douglas, M. J. W. (1966) Occurrence of accessory corpora lutea in red deer, Cervus elaphus. F. Mammal. 47, 152 .

Du Fourn.Loux, J. (1561) La vénerie et l'adolescence. Poitiers.

Fraser Darling, F. (1937) A herd of red deer. Oxford University Press.

Grant, R. (1934) Studies on the physiology of reproduction in the ewe. Trans. R. Soc. Edinb. 58, 1.

HARVEY, W. (1651) Exercitationes de generatione animalium. London.

HEAPE, W. (1901) The sexual season of mammals and the relation of the pro-oestrum to menstruation. Q. Fl microsc. Sci. 44, 1.

LAND, R. B. (1971) The incidence of oestrus during lactation in Finnish landrace, Dorset horn and Finn-Dorset sheep. 7. Reprod. Fert. 24, 345.

Lincoln, G. A. (1971) The seasonal reproductive changes in the red deer stag (Cercus elaphus). F. Zool. Lond. 163, 105.

Lincoln, G. A. \& Short, R. V. (1969) History of a hummel. Deer, 1, 372. 
Lincoln, G. A., Youngson, R. W. \& Short, R. V. (1970) The social and sexual behaviour of the red deer stag. F. Reprod. Fert., Suppl. 11, 71.

Lowe, V. P. W. (1969) Population dynamics of the red deer (Cervus elaphus) on Rhum. F. Anim. Ecol. $38,425$.

MacNally, L. (1968) Highland year. Phoenix, London.

Morrison, J. A. (1960) Characteristics of estrus in captive elk. Behaviour, 16, 84.

PreLl, H. (1938) Die tragzeiten der einheimischen Jagdtiere. Tharandtes Fortliches Jahrbuch, 89, 696.

RoBinson, T. J. (1959) The estrous cycle of the ewe and doe. In: Reproduction in Domestic Animals, Vol. 1. Eds. H. H. Gole and P. T. Gupps. Academic Press, London.

Simkr, D. W. (1965) Reproduction and productivity of moose in Northwestern Ontario. F. Wildl. Mgmt, 29, 740.

Thomas, D. C. (1970) The ovary, reproduction, and productivity of female Columbian black-tailed deer. D.Phil. thesis, University of British Columbia.

Thorburn, G. D., Bassett, J. M. \& SMith, I. D. (1969) Progesterone concentration in the peripheral plasma of sheep during the oestrous cycle. $\mathcal{F}$. Endocr. 45, 459.

TuRBervile, G. (1576) The noble art of venerie or hunting. London.

WhrteHEAD, G. K. (1950) Deer and their management in the deer parks of Great Britain and Ireland. Country Life, London.

Youngson, R. W. (1970) Notes on the rearing of eleven red deer calves in Scotland. F. Wildl. Mgmt, 34, 467 .

Zuckerman, S. (1952) The breeding seasons of mammals in captivity. Proc. zool. Soc. Lond. 122, 827. 